\title{
Foreign Economic Liberalization and Peace: The Case of Sub-Saharan Africa
}

\author{
MARGIT BUSSMANN, GERALD SCHNEIDER AND \\ NINA WIESEHOMEIER \\ University of Konstanz, Germany
}

\begin{abstract}
A typical adage of the globalization literature is that foreign economic liberalization undermines the social fabric of developing countries. This article examines this claim for the sub-Saharan African countries and thus the continent that experienced both low economic growth and a high incidence of armed conflict during the 1990s. Our results yield support for the assertion that economic openness durably pacifies countries once the restructuring of the economy is over. We can, however, not reject the possibility that the distributional consequences of foreign economic liberalization increase the risk of civil war during the implementation of the reform measures. We contrast this 'distributional' model with alternative explanations such as the role of the International Monetary Fund and the level of democracy. A comparative case study on Guinea and Guinea-Bissau lends some illustrative evidence to the claim that compensating the losers of globalization can pacify intrastate relations.
\end{abstract}

Key Words $\bullet$ Africa $\bullet$ civil war $\bullet$ foreign economic liberalization globalization • Heckscher-Ohlin • Ricardo-Viner - Structural Adjustment Programmes

\section{Introduction}

The current conventional wisdom to which the World Bank and other international institutions adhere traces the civil wars in Africa to economic problems. This does not come as a major surprise because the continent simultaneously endured a 'growth tragedy' in the 1990s (Easterly and Levine, 1997) and an upsurge in the number of armed conflicts (Collier and 
Hoeffler, 2002). It is therefore not startling that Elbadawi and Sambanis (2000) ask: 'Why are there so many civil wars in Africa?'

As Sachs and Warner (1995) see it, the rampant protectionism that was especially prevalent in sub-Saharan Africa significantly aggravated the economic problems. Conversely, countries that have liberalized their economies have, in this point of view, been able to escape the trap of economic stagnation and political crisis. Recent quantitative studies suggest that the positive effects of openness are not limited to the economic sphere. Economically integrated countries are more stable than autarkic nations and experience fewer civil wars (Bussmann et al., 2003; de Soysa and Wagner, 2003). Similarly, Harff (2003) demonstrates that economically open nations are less likely to experience genocides. Hegre et al. (2003) find an indirect pacifying effect of trade on internal conflict through the channels of economic growth and political stability.

The expectation of long-term benefits is, however, in considerable contrast to the negative impact that sceptics of globalization associate with increased economic integration. They maintain that foreign economic liberalization has destabilized the fragile developing countries (e.g. Chua, 2002). Brennan (2003: 50) for instance believes that 'globalization . . . visits terrors on the South and on the future, directly through war, starvation and exploitation, and indirectly through the destruction of the atmosphere'. A particularly prominent, but considerably more moderate, globalization critic is Nobel laureate Joseph Stiglitz. He maintains that foreign economic liberalization measures, as they were designed by the International Monetary Fund (IMF), have had negative consequences:

Disillusion with the international system of globalization under the aegis of the IMF grows as the poor in Indonesia, Morocco, or Papua New Guinea have fuel and food subsidies cut, as those in Thailand see AIDS increase as a result of IMF-forced cutbacks in health expenditures, and as families in many developing countries, having to pay for the children's education under socalled cost recovery programs, make the painful choice not to send their daughters to school. Left with no alternatives, no way to express their concern, to press for change, people riot. (Stiglitz, 2002: 20)

He particularly maintains that the costs of economic reform are 'disproportionately' borne by the poor (2002: 67, see also Yusuf and Stiglitz, 2001).

In this article, we examine the two competing claims, arguing that they are reconcilable from the perspective that we call the 'distributional theory of civil conflict'. This approach maintains that the short-term impact of foreign economic liberalization can be negative, but ought to be positive in the long run. The reasons for this double-sided effect are the losses that foreign economic liberalization creates in important segments of the population. Standard approaches in trade theory lead us to expect that in the 
developing world resistance against economic openness should either come from the import-competing industry or the scarce factor, which in these states is capital rather than labour. The first hypothesis is in line with the Ricardo-Viner model, the second with the Heckscher-Ohlin approach.

Proponents of economic integration like Fischer (2003: 10) support the view advanced in this article that one needs to distinguish between the short- and long-term consequences of economic openness: '. . . globalization creates losers as well as winners in the short run'. Our previous research lends some tentative support to the expectation that the risk of conflict might increase in times of foreign economic liberalization. While economic opening did not increase the risk of coups and other measures of domestic instability in the developing world in general (Bussmann et al., 2003), Walter (2003) detects a significant impact of reform measures onto the strike activities of the import-competing industry in Argentina.

In this article, we would like to explore for the continent that endured both low economic growth and a high incidence of civil war whether the double claim of the distributional theory is correct. Accordingly, we use subSaharan Africa as a critical test case and compare the relative explanatory power with standard explanations of civil conflict. The new literature has come to the consensus that 'grievance', 'greed' and weak political institutions are key motives in the decisions of political leaders to engage in civil war (Fearon and Laitin, 2003). We also examine in line with the antiglobalization literature the impact that IMF policies had on the conflict potential within states.

The article is structured as follows: We first justify our selection of subSaharan Africa as test case for our double argument. Next, we present some quantitative support for our claims and select the two countries that make part of the case study. We discuss the broader implications of our results in the conclusion.

\section{Why Sub-Sabaran Africa?}

Foreign economic liberalization and the incidence of civil war are two of the trends that have shaped international politics throughout the past decades. These trends also encroached upon the African countries. As the descriptive evidence presented below suggests, this continent is an ideal testing ground for our general theoretical claim that economic openness might be beneficial in the long run, but runs the risk of being hazardous in the short term. Despite some reform efforts, African states exhibit on average lower economic openness than an average non-African state. Yet, they have faced a much higher risk of falling victim to civil war than the average state on other continents. If trade and foreign economic liberalization are in any way 
systematically linked to armed conflict, this relationship must be particularly distinct in Africa. We use the tragic combination of protectionism and political violence as an illustration for a novel theoretical argument which we sketch later and develop fully in another article (Bussmann and Schneider, 2004). ${ }^{1}$

By introducing the CACAO index on trade policies and institutional arrangements, Martin (2005) shows that most developing countries have become more open to the world economy during the last two decades. ${ }^{2}$ Figure 1 reveals that foreign economic liberalization also caught on in subSaharan Africa throughout the past 25 years, but to a lesser extent than on other continents. At the end of the 1970s, countries in sub-Saharan Africa have been on average more protectionist than the states in other developing regions. By 1987, this gap had nearly closed, but at the end of the 1990s it had become even wider. The 'rush to free trade', as Rodrik (1994) put it, discloses important regional divergences. While the rest of the developing countries notably liberalized their economies at the beginning of the 1990s, sub-Saharan Africa even experienced a decline in openness.

The lack of openness also becomes apparent with Africa's world export share falling from $3.5 \%$ in 1970 to $1.5 \%$ in 1995 or its share in world imports which declined from $4.5 \%$ to $1.5 \%$ in the same period (Bigsten and Durevall, 2002). Collier and Gunning (1999) mention that by the 1980s Africa's economic openness lay far behind that of other regions. That is why a high number of structural adjustment programmes (SAPs) were introduced in the early 1980s aiming at the market integration of this continent. Yet, many reform measures were only partially implemented (Van de Walle, 2001).

It has been widely noted that the incidence of civil war rose until the mid1990s and then fell to a lower level (e.g. Gleditsch et al., 2002). This trend does not, however, coincide with the development in sub-Saharan Africa where an upsurge in the number of conflicts occurred after 1995, as Figure 2 shows. It is no surprise that development agencies now perceive war as one of the main obstacles for economic growth in these countries; Collier et al. (2003) speak of the 'conflict trap' that development policy faces. Based on a collection of case studies, Stewart and Fitzgerald (2001) see in civil war a major cause of poverty. Quantitative evidence for Uganda, for instance, emphasizes that 'the political disturbances had a negative impact on investment, savings, tax revenue, government expenditure, exports and imports, and a positive impact on defence expenditures' (Matovu and Stewart, 2001: 263). Murdoch and Sandler (2002) have furthermore uncovered dramatic short-run economic effects of armed conflict in the country in which the war took place but also in neighbouring states. In turn, Collier and Hoeffler (2002: 14) attribute the rising trend of conflict in Africa to the poor economic performance of this continent. As the 'Great 
Figure 1

Mean Trade Openness ( 0 is 'closed', 7 is 'open')

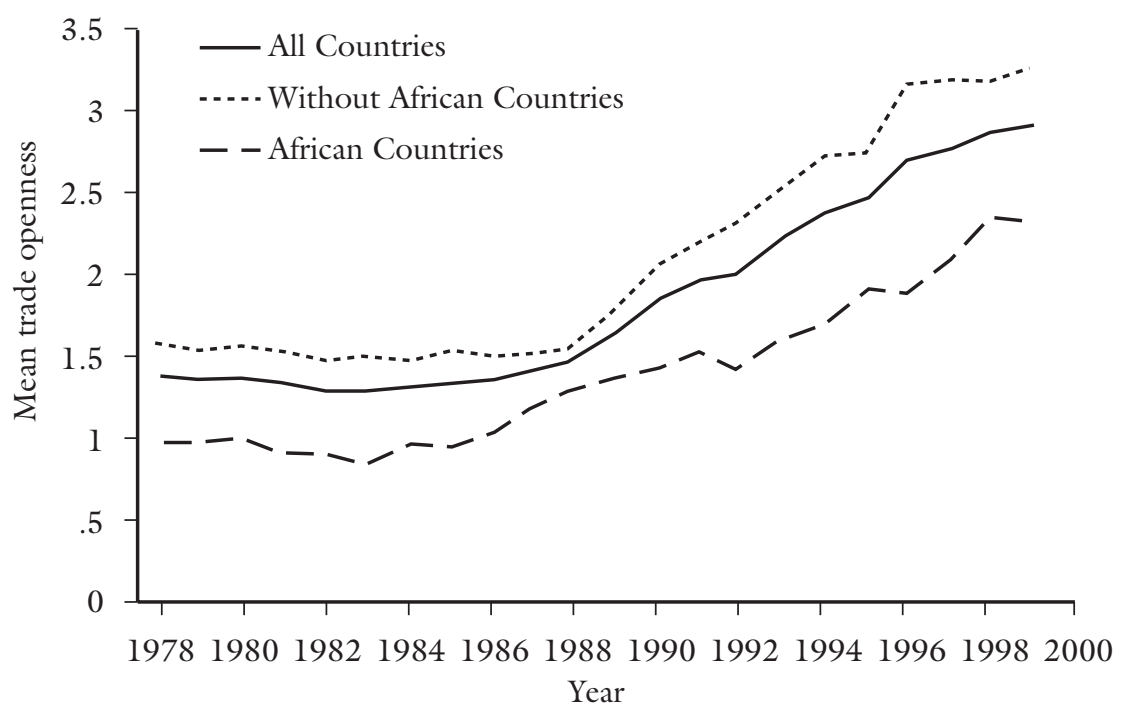

Source: CACAO dataset (Martin, 2005).

African War' and other armed conflicts illustrate, the plunder of natural resources accompanies the conflicts and renders them particularly difficult to end (Collier and Hoeffler, 2004; Olsson and Congdon Fors, 2004).

We will bridge the gap between the research agendas on economic openness and civil war and draw attention to the question of whether or not economic liberalization is likely to fan the flames of domestic violent conflict. Opening the foreign economic system is no panacea - especially not in subSaharan Africa where economic reforms have gone hand in hand with the structural adjustment programmes (Bigsten and Durevall, 2002) - so that economic liberalization never means the mere abolition of tariffs and other trade barriers.

\section{The Link between Economic Reforms and Civil War}

One key result in the social sciences, the comparative advantage theorem of Ricardo, shows indirectly how free trade can lessen the likelihood of violent conflict. According to this model, a unilateral move towards free trade allows a country to specialize its economic production in those areas where it is particularly competitive. Proponents of globalization (Sachs and 
Figure 2

Incidence of Civil War

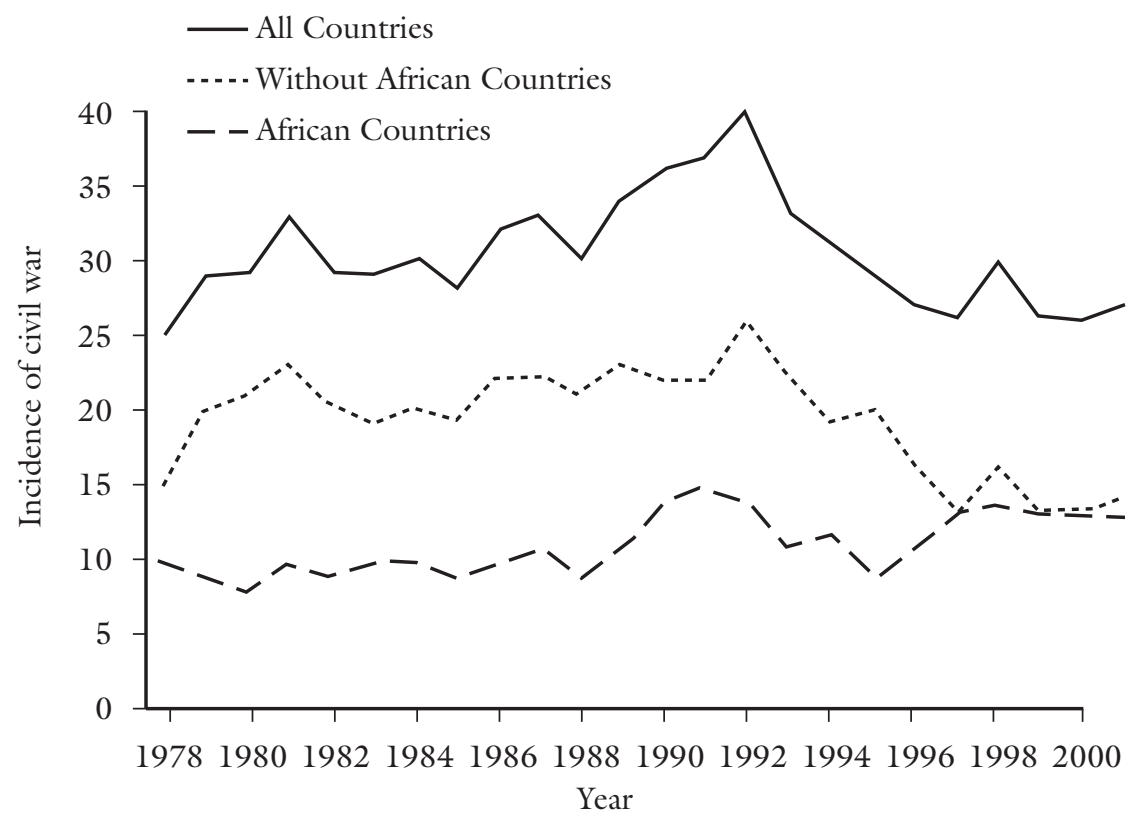

Source: Armed Conflict 1946-2001 dataset (Gleditsch et al., 2002).

Warner, 1995; Fischer, 2003) and also some of its critics (e.g. Yusuf and Stiglitz, 2001; Stiglitz, 2002) see trade accordingly as a positive-sum game, which is mutually beneficial for the trading partners. As countries exploit their comparative advantage and are thus enabled to produce and consume more goods, the growth rates of the economies increase. Dynamic gains from trade, like the acquisition of new knowledge or changes in institutions, have even stronger long-term benefits than static gains that are inherent in the theory of comparative advantage (Thirlwall, 2003). Because the opportunity costs of conflict grow in line with increased specialization, one of the key motives of social protest, discontent with the economic policies of the government, should become less manifest in an economically integrated country.

The Stolper-Samuelson theorem and similarly the Heckscher-Ohlin model show that in each country the abundant factor will gain from trade. Since this will typically be the greatest part of society in developing countries, namely unskilled work, it is assumed that the population as a 
whole will be better off. In sectoral terms, agriculture which employs the largest share of these workers should profit from the growing integration into world markets. The rent seeking literature has demonstrated for a long time that state monopolies and other discriminating regulations have negatively affected the income of farmers (e.g. Bates, 1981).

However, the benefits of economic openness will only take effect after some years, leaving a risk of instability in the short run. Reform measures that integrate an economy more fully into the world market will redistribute income from the inefficient to the efficient sectors and workers within an economy. The discrepant effects that foreign economic liberalization have are conflict-prone if the winners are not able or willing to compensate the losers economically. Although he did not directly discuss the problem of instability, Rogowski's (1989) model of coalition-building in times of changing patterns of trade can be used as a starting point to understand the ambiguous political nature of increasing economic openness. He drew on the Stolper-Samuelson theorem and thus a standard model that is based on the three factors: land, capital, and labour. Assuming that no single country can be rich in land and labour, the land-labour ratio defines a country's endowment with these factors. Depending on the kind of economy, Rogowski either predicts from this simple model an urban-rural or a class conflict that should accompany economic liberalization in developing countries. In the first case, land is the abundant factor which would benefit. Capital and labour, normally based in an urban environment, are scarce and would seek protection. In the latter case, the economy is endowed with labour, and capital and land are scarce, thus leading to a coalition of land owners and capitalists supporting protectionism. We believe, based on Bates' (1981) pioneering work on the political economy of farming, that the first model is more realistic for the African countries. The behavioural consequence would be that farmers would strive for liberalization while the urban elites would oppose this, possibly with the threat of using force. Some country experiences support our claim that the urban-rural cleavage is a key for our understanding of foreign economic liberalization in Africa. In an indepth case study, Acemoglu et al. (2003: 83) for instance explain the economic and political success of Botswana through a political contract that prevented urban interests 'to extract resources from the rural sector'.

Changing incentives do not directly translate into a growing likelihood that actors will use force. The standard formal models of civil war, especially the celebrated approach of Collier (2000), who framed rebellion as a quasicriminal activity, stress the importance of rent capture as a key motive of civil conflict. Obviously, the threat of losing income as a consequence of economic reforms should be as powerful a reason to become politically active as the prospect of acquiring income. In democracies, the losers of 
global economic integration will take it to the street or fight against their potential loss of income in the national parliaments. In semi-democracies or autocracies, where civil societies are less strongly developed, protesters have often to resort to other means to achieve their political goals. The use of armed violence ranks highly among them.

Economic liberalization thus not only shakes an economy severely, but it also endangers the stability of the entire political system. The rent seeking system, on which the stability of the regime relies, is at risk through the abolition of licenses, monopolies and tariffs. The privatization of state-led firms and the downsizing of the public service sectors are further core elements of adjustment and restructuring programmes and will cause extensive layoffs of state employees. If the threat of losing income looms sufficiently large, the well-organized elites are likely to oppose such reform steps to preserve the status quo. This is especially the case in countries where those loyal to the incumbent leaders staff the bureaucracy (Geddes, 1994). Economic reforms impose high costs on politicians, whom the public choice literature aptly considers to be support- rather than welfaremaximizers. We expect therefore that the political apparatus will most likely oppose change.

Another possibility for conflict arises after the reform has been implemented. First, the potential winners will see an increase in their personal wealth. This will enhance their willingness to call for political reform that acknowledges these changes. The groups that profit from foreign economic liberalization may consequently challenge the incumbent. In a democracy this would be feasible through elections. In a repressive regime this may lead to violent conflicts if the incumbent is not willing to change the political distribution of power through further reforms. Second, it can be assumed that the losers will organize protests against the measures implemented if the government does not abide by its eventual promise of compensation. This also might propel disgruntled losers to organize violence or join rebel groups in order to gain lootable income, which provides short-term economic relief.

In many developing countries, the main reform impetus came from international financial organizations rather than the domestic opposition. How the activities of international organizations and especially the IMF influence the domestic conflict potential is disputed. Globalization sceptics fear that the uniform implementation of the 'Washington consensus' aggravates the crisis potential. Azam (2001) offers some evidence that the destruction of inefficient redistributive practices has increased the risk of conflict in countries such as Ivory Coast. The other side mainly uses counterfactual arguments, pointing out that the risk would have been even greater without economic reforms. As Jensen (2004: 200, see also Oately, 2004), 
for instance, maintains, ' $\ldots$ although there is considerable evidence that IMF programs can have a negative impact on macroeconomic performance, there seems little conclusive evidence that IMF programs are generally politically destabilizing'.

The theoretical arguments put forward so far can be summarized as follows: We assume that opened countries benefit from foreign trade in the long run, showing higher levels of development, growth and stability. However, we expect an increased risk for conflict, even a violent one, in the short run. This double hypothesis is the core of what we call the 'distributional theory of civil war'.

\section{Trade Liberalization and Civil War in Sub-Sabaran African States, 1980-2000}

In this section, we will examine the effects of trade openness and liberalization on the outbreak of internal wars in 37 sub-Saharan African countries for the years from 1980 to 2000 . We will briefly outline our research design here. The dependent variable 'onset' is dichotomous and takes the value $l$ if a civil war starts in a given year and zero otherwise. The long-term effects of trade openness are measured as the natural logarithm of (exports + imports)/GDP. Trade liberalization, our indicator for the shortterm effects of free trade, is the yearly change in the CACAO indicator. As control variables we include regime type, level of development, population, mountainous terrain and both concessional and non-concessional IMF flows. The operationalization and data sources of all our variables, together with the rationale for selecting the control variables, are described in more detail in the appendix. Table 1 summarizes the expected signs of our independent variables. As there are no prior studies on the impact of IMF flows, we expect no systematic relationship. We will utilize a pooled timeseries cross-section logit model with robust estimation of variance.

The control variables point in the expected direction, as reported in the first column of Table 2 . The positive sign of democracy and the negative sign of its squared term support the inverted U-curved character of this relationship, i.e. democracies and autocracies are less prone to conflict, whereas countries with intermediate levels of democracy are more likely to experience civil unrest. The two variables are not individually but jointly significant $(p<.05)$. The inflection point of the inverted U-curve is at 5.68 on the Polity scale. ${ }^{3}$ For our sample this means that the majority of all cases are on the upward slope of the parabola (397 vs 90 cases). In only $18 \%$ of all cases does increasing democratization reduce the risk of conflict. ${ }^{4}$ The level of development is negatively related to civil war and statistically significant. Countries that are economically developed are less likely to be involved in an 
Table 1

Expected Influences of the Independent Variables on Conflict

Independent Variable

Expected Influence on Conflict

internal war. Mountainous terrain increases the chances for a country to experience the onset of civil war, thus supporting the evidence of Fearon and Laitin (2003). Population size is significant but has a negative coefficient. We keep this variable in the model for its theoretical importance concerning the trade variables.

Trade openness, our measure for the long-term effect, has a conflictreducing impact and is significant at the $10 \%$ level. As expected theoretically, trade liberalization increases the likelihood of conflict outbreak, a result that is highly significant. The results are robust to various alternative model specifications ${ }^{5}$ and estimation techniques. ${ }^{6}$ Thus, our theoretical expectations are supported by the empirical results, in the long term as well as in the short term. Both effects are also substantively important; increasing the trade-to-GDP ratio by 1 standard deviation reduces the likelihood of conflict by $46.3 \%$ (from a baseline probability of .029 ). The short-term effect of liberalization, i.e. changing the CACAO-indicator from 0 to 1 , heightens the risk of civil war onset by $170.6 \%$. These contrasting effects thus lend support to our claim that the impact of growing market integration is ambiguous. If policy-makers do not take the redistributive effects of foreign economic liberalization into account, they risk fostering social tensions.

The second column serves the purpose of comparison with a global sample. All variables have the same signs in both models; mountainous terrain is significant at $p<.11$ and population is not significant in the global sample. The main difference is that trade openness is not at all significant in the global sample. Altogether, our model fits better for the African sample.

In the third and fourth columns of Table 2 we add variables for IMF flows to see if instability is due to a SAP or to trade liberalization. The results of 
Table 2

Effects of Foreign Economic Openness and Liberalization on Civil War, 1980-2000

\begin{tabular}{|c|c|c|c|c|}
\hline & $\begin{array}{c}\text { (1) } \\
\text { African } \\
\text { Sample }\end{array}$ & $\begin{array}{c}(2) \\
\text { Global } \\
\text { Sample }\end{array}$ & $\begin{array}{c}(3) \\
\text { African } \\
\text { Sample }\end{array}$ & $\begin{array}{c}(4) \\
\text { African } \\
\text { Sample }\end{array}$ \\
\hline Openness $_{t-1}$ & $\begin{array}{c}-1.3697^{*} \\
(0.7525)\end{array}$ & $\begin{array}{l}-0.4450 \\
(0.5073)\end{array}$ & $\begin{array}{l}-1.4497^{* *} \\
(0.7279)\end{array}$ & $\begin{array}{l}-1.4894 * * \\
(0.7324)\end{array}$ \\
\hline Liberalization $_{\mathrm{t}-1}$ & $\begin{array}{l}1.0478^{* * *} \\
(0.3844)\end{array}$ & $\begin{array}{l}0.5617^{* *} \\
(0.2542)\end{array}$ & $\begin{array}{l}1.0850^{* * *} \\
(0.3994)\end{array}$ & $\begin{array}{l}1.0538^{* * *} \\
(0.3894)\end{array}$ \\
\hline $\begin{array}{l}\text { Economic } \\
\text { development }_{t-1}\end{array}$ & $\begin{array}{l}-1.0549 * * \\
(0.4772)\end{array}$ & $\begin{array}{l}-0.5068^{* *} \\
(0.2047)\end{array}$ & $\begin{array}{l}-0.9689^{* *} \\
(0.4263)\end{array}$ & $\begin{array}{l}-1.0028 * * \\
(0.5101)\end{array}$ \\
\hline Democracy $_{\mathrm{t}-\mathrm{l}}$ & $\begin{array}{c}0.3470 \\
(0.2304)\end{array}$ & $\begin{array}{l}0.3053^{*} \\
(0.1566)\end{array}$ & $\begin{array}{c}0.3381 \\
(0.2240)\end{array}$ & $\begin{array}{c}0.2777 \\
(0.2274)\end{array}$ \\
\hline Democracy & -0.0104 & -0.0115 & -0.0095 & -0.0074 \\
\hline $\begin{array}{l}\text { Squared }{ }_{t-1} \\
\text { Mountainous terrain }\end{array}$ & $\begin{array}{l}(0.0106) \\
0.0179 * *\end{array}$ & $\begin{array}{c}(0.0070) \\
0.0101\end{array}$ & $\begin{array}{r}(0.0103) \\
0.0157^{*}\end{array}$ & $\begin{array}{l}(0.0106) \\
0.0161 * *\end{array}$ \\
\hline Population & $\begin{array}{c}(0.0081) \\
-0.3283^{*} \\
(0.1912)\end{array}$ & $\begin{array}{c}(0.0062) \\
-0.0788 \\
(0.1333)\end{array}$ & $\begin{array}{c}(0.0082) \\
-0.2082 \\
(0.1960)\end{array}$ & $\begin{array}{c}(0.0078) \\
-0.2133 \\
(0.1946)\end{array}$ \\
\hline $\begin{array}{l}\text { Non-concessional IMF } \\
\text { net flows/GDP }\end{array}$ & & & $\begin{array}{c}7.4211 \\
(10.1898)\end{array}$ & \\
\hline $\begin{array}{l}\text { Concessional IMF net } \\
\text { flows } / \mathrm{GDP}_{\mathrm{t}-1}\end{array}$ & & & & $\begin{array}{l}-2.0956 \\
(3.7254)\end{array}$ \\
\hline Constant & $\begin{array}{l}10.1987^{* *} \\
(5.1919)\end{array}$ & $\begin{array}{c}1.4902 \\
(3.1436)\end{array}$ & $\begin{array}{l}8.9940^{*} \\
(5.2138)\end{array}$ & $\begin{array}{c}9.6897^{*} \\
(5.7190)\end{array}$ \\
\hline$N$ & 487 & 1361 & 404 & 429 \\
\hline Pseudo $R^{2}$ & .17 & .07 & .19 & .16 \\
\hline
\end{tabular}

Note: The first number in each cell is the coefficient. Robust standard errors appear in parentheses. ${ }^{*} p<10 \%$; ${ }^{* *} p<5 \%$; ${ }^{* *} p<1 \%$, two-tailed tests.

trade openness and trade liberalization remain significant even when we control for IMF flows. The variables accounting for concessional and nonconcessional IMF flows in relation to GDP are, by contrast, statistically not significant. If we employ the contemporaneous version of these variables as predictors, non-concessional flows are positively and statistically highly significant. This result seems to confirm the suspicion of globalization sceptics that the implementation of IMF programmes is indeed positively associated with the occurrence of armed conflict. As the usage of a nonlagged variable, however, creates a severe endogeneity problem, we believe that the results reported in Table 2 are more accurate. ${ }^{7}$ Most importantly, 
the double conjecture advanced in this article that foreign economic liberalization can exert both a positive and a negative effect remains robust in either specification.

\section{Selection of Countries: Trade Liberalization in Two West African States}

In a next step, we conduct comparative case studies to gain further insight into the causal relationship between trade liberalization and civil conflict concentrating in particular on the short-term effects. To avoid selection bias, we need to compare countries or, more precisely, country years that differ on the dependent variable. Table 3 shows which cases can be used for a most similar case-research design. It lists all episodes of liberalization, specified by the yearly changes in the CACAO-indicator. We divided the table according to whether the countries witnessed an onset of civil war one or two years after the trade liberalization.

The majority of cases did not experience a civil conflict in the direct aftermath of liberalization (see column 2). However, we argue that not all but some countries undergo disorder after trade liberalization, and we would like to uncover the relevant factors that might be responsible for this relationship. For this purpose, we contrast a case from the first column with a case from the second column.

We examine in more detail trade liberalization in Guinea-Bissau where a civil war broke out one year after an episode of liberalization in 1997. 8 Guinea serves as an example demonstrating the opposite, a similar country in terms of geographic location, government type and labour force occupation as Guinea-Bissau; yet, trade liberalization was not followed by civil conflict in the former state. Our aim is to explain these divergent country experiences. We draw information about the two countries primarily from secondary sources and two yearbooks (Keesing's Contemporary Archives and Afrika Jabrbuch).

\section{Liberalization in Guinea-Bissau}

The civil war that ravaged Guinea-Bissau in 1998 pitted two groups against each other, the government and the military elite (Rudebeck, 2001). The internationally required cuts in military spending had deepened this fault line. Economic reform and, relatedly, foreign economic liberalization are thus likely causes of the conflict.

\section{Political Development}

After a war of liberation the Portuguese troops withdrew from GuineaBissau and independence was declared in 1974. The colonial elite were 
Table 3

Episodes of Liberalization

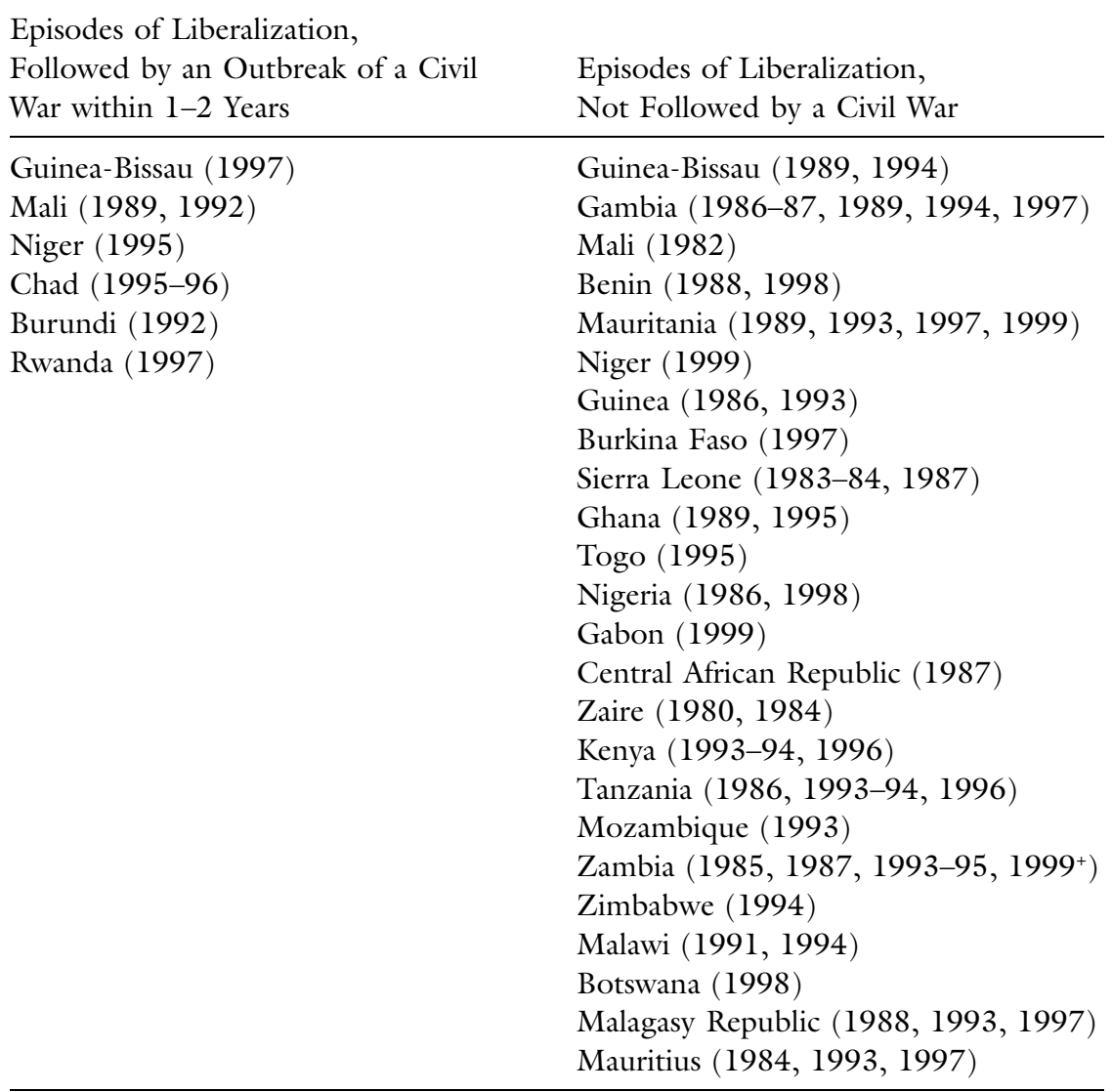

Source: CACAO data set (Martin, 2005), Armed Conflict 1946-2001 dataset (Gleditsch et al., 2002).

replaced by the leadership of the Partido Africano da Independência da Guiné e Cabo Verde (PAIGC). Guinea-Bissau quickly became the scene for continuing power struggles among various government ministries and party leaders. In 1980 João Bernardo Vieira, an important military leader, overthrew the regime. He was able to extend and consolidate his usurped power, centralizing the PAIGC further and increasingly using the party instead of the military for personal advancement. In 1984, Vieira introduced a new constitution which granted himself almost absolute power (Forrest, 
1987). Several coup attempts revealed how deep the cleavage between the government and the military was. In May 1991 a new constitution introduced a series of changes, the most important one being the abolition of the supremacy of the PAIGC. The first elections, in which the former unity party PAIGC won the majority of the parliamentary seats, were held three years later. In the presidential elections, the party's candidate, Vieira, was victorious in the second round.

Violence became more likely when Guinea-Bissau went through political liberalization and turned out to be an inconsistent political system. President Vieira tried to adhere to his strategy of coercion and distribution, but the political changes undermined the effectiveness of this carrot and stick strategy. In 1991, after the introduction of the multi-party system, the opposition organized public demonstrations against the government. The first authorized public demonstration with about 30,000 participants took place a year later.

\section{Economic Liberalization}

Vieira's seizure of power in 1980 marked a turn in the country's economy. Guinea-Bissau had followed an import-substitution strategy after its independence (Zejan and Kokko, 1998). The new leadership soon reached a consensus that these policies were no longer sustainable and established contacts with the World Bank and the IMF. The government launched a first reform plan in 1983, which was followed by a 'Plan for Economic Stabilization'. The year 1986, during which the Vieira government introduced a series of measures, was a turning point towards economic liberalization. The reforms, which ranged from the abolition of state monopolies to the establishment of a market oriented price system, found the approval of the Bretton Woods financial institutions; the first SAP started in 1987 (Aguilar and Stenman, 1997).

But these measures did not live up to expectations. The following years saw periodic suspensions of two SAPs and one Enhanced Structural Adjustment Facility (Kovsted and Tarp, 1999). The second SAP, launched in 1989, was put on hold because of poor performance. Because vested interests could successfully block the reforms, the demanded restructuring of the public service was delayed and privatization advanced only slowly (Monteiro, 1996). On this basis, the government and the international financial institutions developed a new strategy for 1994-97 and a third structural credit was approved. This time, the country was able to achieve most of the aims set up in this programme (Kovsted and Tarp, 1999). 


\section{Public Reactions}

Increasing social unrest characterized the 1990s as teachers and public servants launched strikes and discontent in the military increased. The protesters felt especially threatened by the economic crisis and by the government's inability to pay wages to its employees. Rising costs of living accompanied the austerity measures of the government (Zejan and Kokko, 1998). The Bretton Woods institutions particularly demanded a reduction in public service employment by $30 \%$. The redistributive effects of this requirement were immense in a country like Guinea-Bissau where the public sector dominates the economy. In the mid-1990s, the public service employees accounted for $80 \%$ of all salary dependents. Due to the poor state of the economy, it was unlikely that the unemployed teachers could easily find work in the private sector. The ministries and other public institutions were unable to act as mediators in the widespread strikes, not the least because they lacked appropriate management capabilities (Zejan and Kokko, 1998).

The SAP with its threat to cut defence spending did not meet sympathy in the military. Many military officers feared they would lose their privileges as reports from the Cape Verdian Islands spread that officials had lost their houses and flats granted to them by the state (Schiefer, 2002). The government reduced the military budget from 3.6\% of GNP in 1993 to $2.8 \%$ in 1995 and the military personnel from 12,000 in 1991 to 7,000 in 1997 (Kovsted and Tarp, 1999). Several intended or planned coups indicated how deep the discontent was within the army.

These domestic tensions were aggravated in 1997 when Vieira carried through the entry of Guinea-Bissau into the Union Economique et Monétaire Ouest-Africaine. This regional integration treaty aims at coordinating the economic policies of the member states and at harmonizing the external tariff. Many of his opponents saw Vieira's move as a betrayal of the ideals and the independence gained in the liberation war but also as giving neighbouring Senegal, with French pressure, more influence in national affairs (Wegemund, 1999).

\section{Civil War 1998-99}

The armed conflict began in February 1998 when Vieira accused the army's Chief of Staff, General Ansumane Mané, of illegal arms sale to the Casamance rebels in bordering Senegal and suspended him as a result of demands from the Senegalese government (Kovsted and Tarp, 1999). Relations with Senegal were already strained because the Guinean military was suspected of supporting the Casamance rebels. Mané was highly popular among the soldiers as he had called for payment of their outstanding salaries 
and urged Vieira to improve the troops' living conditions. Mané's answer to the suspension was an attempted coup leading to the eruption of fighting between rival factions of the army about the control of the capital Bissau in June 1998. The majority of soldiers stood loyal to Mané, and Vieira had to call on a joint defence pact between Guinea-Bissau, Senegal and Guinea to send troops in his defence (Gaillard, 1999).

Under the leadership of the Economic Community of West African States a peace agreement was concluded in Abuja, Nigeria, in November 1998. The agreement replaced the Senegalese and Guinean soldiers by a West African Force of 600 soldiers. For an interim government the ministries and central secretariats were divided equally between the military junta and Vieira's supporters and elections were planned for late 1999. Fighting broke out again as Vieira did not abide by the Abuja agreement and refused to disarm 600 of his troops. He was eventually overthrown and left the country in 1999.

\section{Liberalization in Guinea}

Although the risk for conflict was equally high in neighbouring Guinea, the government under Colonel Conté could prevent the outbreak of armed violence during the time of economic reform and foreign economic liberalization. Guinea fell victim to a civil war in other circumstances. In the year 2000, Guinea was drawn into the struggles for territory and mineral wealth that had engulfed neighbouring Liberia and Sierra Leone. It is, however, not this conflict that we have to explain here but rather the absence of a civil war after the foreign economic liberalization in 1986 and 1993.

\section{Political Development}

After the departure of the French, the Parti Democratique de Guinée assumed political power, becoming the sole legitimate political party. In 1984 after Sekou Touré's death, the ruler of Guinea since independence, the army immediately seized power in a coup led by Colonel Lansana Conté. In 1989, Conté announced plans for a move towards democratic government, in particular the creation of a multi-party system. The population accepted the new constitution by national referendum a year later, together with the commitment to return power to a civilian government. Despite these promises the president and the military remained central figures. Conté won the first presidential elections under the new constitution against seven other candidates three years later. In February 1996, he survived a coup attempt, after which he assumed personal control of the country's armed forces.'

The opposition, frustrated with the long transition period and the halfhearted democratization, demanded the establishment of an independent 
and sovereign election commission and a transition government. Clashes between demonstrators and the police intensified in connection with the 1993 elections. Yet these disputes did not escalate into a civil war. Additional political protests could be observed in response to the suppression of the opposition, especially regarding repeated arrests of opposition leader Alpha Condé. After the presidential election, the opposition's demands and demonstrations continued with respect to the upcoming parliamentary elections (that were delayed until 1995) in which the president's party won the majority of the seats. International election observers were satisfied but the opposition spoke of fraud. ${ }^{10}$

\section{Economic Liberalization}

The legacy of Guinea's socialist First Republic under Sekou Touré was to leave succeeding governments with the problems of one of the most distorted economies in West Africa, namely overvalued exchange rates, inefficient state enterprises, trade barriers and subsidies. The economic situation was so grave 'that virtually everyone lost under the old system' (Stryker, 1990: 195). The Guinean economy, dependent on the exploitation of mineral resources, in particular bauxite and alumina but also gold and diamonds, was sustained through the mining enclaves. The country's exports were concentrated in bauxite and the Guinean economy became increasingly dependent on food imports. With falling bauxite prices, economic growth slowed down. The agricultural sector stagnated; in 1990 agricultural exports accounted for only $3 \%$ of the total export earnings (Stryker, 1990).

Conté's government responded after the seizure of power with a liberalization programme. With the support of the IMF and the World Bank an economic and financial reform programme was agreed. The liberalizing trade reforms, which began in 1985, simplified the tariff structure and reduced import rates. The non-convertible national currency was devaluated about $92 \%$ in 1986 and changed to the Guinean franc, accompanied by price adjustments. In 1993, further trade liberalization measures facilitated the import of goods (Campell and Clapp, 1995).

At the request of the international financial organizations structural adjustment was undertaken. The SAP demanded that the government reduce its involvement in economic activities and push privatizations forward. Liquidation of state-owned banks and enterprises in the industrial sector and their replacement by private or semi-public enterprises was envisioned but moved forward slowly (Teriba, 1991). Public investment was redirected towards basic infrastructure. As a condition for the adjustment programme with the IMF and the World Bank the government considerably 
reduced its expenditure as a percentage of GDP during the 1980s (Campell and Clapp, 1995; Sahn et al., 1997). Social disturbances, an attempted coup in 1996, increases in salaries and decreasing aluminium prices slowed down the reforms. Thus, the results remained modest but inflation was contained, economic growth rates increased, and the trade balance improved. In 1997, the IMF approved the second Enhanced Structural Adjustment Facility, designed to open up the economy further and attract foreign investment.

On top of that, Guinea underwent a public sector retrenchment programme that reduced the number of public sector employees by $30 \%$. This proved to be a difficult undertaking as not many job opportunities are available in the small formal wage sector. Based on a household survey in Conakry, Sahn et al. (1997) showed that former public sector workers had difficulties in finding employment. Yet, once they had found a new job, laid off workers experienced similar wage increases as those who stayed in the public sector. This confirms that the general wage increase, previously announced by Conté, materialized. From 1986 to 1989, real public sector wages rose by $118 \%$. Compared to other households, retrenched workers were not poor, they just experienced a partial redemption of their privileged position. The Guinean government gave out severance payments which additionally mitigated the effects of the public retrenchment (Sahn et al., 1997). The Conté government also kept the urban civil services happy through its preservation of the ration-card systems. This allowed the public employees to buy imported food at a fraction of the market price (Clapp, 1994).

\section{Public Reactions}

As indicated, social protest centred on demands for more democratization and against the suppression of political antagonists. The economically motivated civil unrests referred largely to the demands of the SAP. After the government's announcement of extensive savings in public expenditure in 1991 the unions called for a general strike and numerous demonstrations took place; teachers demanded wage increases and students better financial support. Conté responded more than once to the demands of protesters. For example, the currency and price reform of 1986 led to price increases of consumer goods such as rice, gas, oil and services. At the same time, public employees received a contribution to the costs of living as compensation. ${ }^{11}$ In the aftermath of a violent demonstration by students and the unemployed directed against rising consumer prices in 1988, Conté announced a price freeze, requesting traders and shopkeepers to return to the previous prices. In 1996, Conté was seriously challenged by a rebellion of soldiers who demanded outstanding payments and increased pay as well as the dismissal of 
the minister of defence. Parts of the army used the chaotic situation for an attempted coup against Conté. The president gave in to the demands of the soldiers and took over the defence ministry.

\section{The Two Countries in Comparison}

After a military coup of the socialist regimes in Guinea and Guinea-Bissau, both military leaders Conté and Vieira turned to the Bretton Woods financial institutions for help and started to liberalize both the economy and the political system. In both countries, the market-oriented economic reforms were designed to enhance trade liberalization, to implement a price reform and to cut public spending, bearing the potential for elite conflicts. Elite conflicts were less concerned with overthrowing a regime but rather with gaining benefits (Chazan et al., 1988). In particular, measures connected to the downsizing of public spending triggered protests from privileged parts of the population - government employees, students, teachers and the military - in both countries. Government workers and the urban population were most severely affected by a public retrenchment programme, whereas for other parts of the population a decline in public spending meant increased investment through saving in the years to come (Sahn et al., 1997).

Where the countries are set apart is in the respective governments' answer to the protesters' demands. The differences between the two government approaches are striking. Concessions to the elite are necessary to ensure survival in an elite conflict. A typical answer is changing appointments and shifting policy or raising salaries in public service (Chazan et al., 1988). This is what the Guinean president perfectly understood. Colonel Conté relied heavily on compensations and on several occasions gave in to the demands of the protesters. Thus, the unrests in Guinea did not culminate in a civil conflict. In Guinea-Bissau, President Vieira did not meet the protesters' demands and was thus not able to prevent an escalation of the conflict.

A crucial difference between the countries is the role the military played. Soldiers and officers were primary victims of the economic reforms, as the reduction of public spending especially affected the defence budget. Yet, the Guinean president gave in to demands of the military for increased pay after a rebellion, whereas in Guinea-Bissau an attempted coup escalated into civil war. President Vieira did not counteract the dissatisfaction in the military with distributive measures but instead preferred to directly confront the leader of the military upheaval.

Concerning political liberalization, after a socialist past both countries underwent measures of democratization, introduced by the respective military leaders who won the elections. Guinea-Bissau was more successful 
in establishing a democratic multi-party system, whereas the Guinean president kept a tight control by suppressing and impeding the opposition, accompanied by violations of human rights. The sluggish democratization process in Guinea was responsible for a good deal of protests related to demands for participation. In Guinea-Bissau fewer purely political demonstrations took place. Thus, political protests do not seem to be directly responsible for the outbreak of this civil war.

\section{Conclusion}

This article has analysed the claim put forward by globalization critics that foreign economic liberalization and other reforms propagated by the Bretton Woods institutions and implemented by previously protectionist regimes undermine the social fabric of developing countries. Although the distributional theory of civil war expects a generally beneficial impact of economic openness, it advances in line with modern trade theory the hypothesis that economic opening destabilizes countries in the short run. This instability does not necessarily have to lead to the eruption of armed violence, as Walter's (2003) detailed analysis of Argentine demonstrates. The escalation of social discontent to civil wars is more likely in countries where social protests cannot easily be channelled into peaceful protests, strikes or other non-armed means to resolve social tensions.

Our evidence supports the assertion that foreign economic liberalization has increased the risk of civil war in sub-Saharan Africa, a region where political systems are especially fragile and effective mechanisms to manage social conflict rare. We have substantiated our claims with a comparative case study. The two countries under examination - Guinea and Guinea-Bissau - had a similarly high risk of experiencing armed violence after their governments introduced wide-reaching reforms of their foreign economic policies. The analysis shows that Guinea seems to have avoided a civil war in the mid-1990s because its President was able to rely on a carrot and stick strategy, while his counterpart in Guinea-Bissau was either unable or unwilling to compensate the losers of economic reform and foreign economic liberalization. A crucial role can be attributed to the loyalty of the military (Weede and Muller, 1998) that was affected by the economic reforms.

Our case studies point to the importance of examining the role of structural adjustment programmes in more detail. Although we have tested for the possible impact of IMF credits, we could not analyse the effect of varying degrees of austerity on domestic stability. Further research should therefore take a close look at the content and the consequences of IMF conditionality in relation to domestic conflict. Simply adding the amount of IMF financial flows to our statistical model did not provide us with 
conclusive insights. A more differentiated analysis that accounts for the specific conditions of the structural adjustment requirements is, in our view, urgently needed. We also suspect that the starting point and the sequence of economic liberalization are important intervening variables (Grosh, 1994).

Although the evidence that we presented is tentative, it alerts us to the fact that not all measures that are economically efficient are also politically feasible. Reforms that are implemented purely at the expense of one social group are endangered if no compensation is made. Obviously, this is not a plea for subsidizing ad nauseam industries and sectors that cannot live up to the demands of the world market. But we believe, in line with Azam (2001), that civil wars might occur in sub-Saharan Africa not least because of the failure to redistribute efficiently. As our results suggest, an implementation of the 'Washington consensus' that does not take these political conditions into account carries a high risk of failure.

\section{Appendix: Description of Variables and Data Sources Dependent Variable: Civil War Onset}

Our dependent variable is the onset of civil war. We use the 'Armed Conflict Dataset' Version 1.2. (Gleditsch et al., 2002) and concentrate on two types of conflicts listed in the data set, internal conflict and internationalized internal conflict, but limit our analyses on conflicts that are located in the country of reference. We generated a dichotomous dependent variable, i.e. the variable is 1 if the threshold of 25 battle-related deaths has been crossed and 0 if no internal war took place in a country. As we are primarily interested in the onset of a civil war, we drop all subsequent years of an ongoing conflict.

\section{Independent Variables}

\section{Economic Openness}

Regarding the long-term effects of free trade, we will estimate the actual trade flows, i.e. the sum of exports and imports divided by GDP, a commonly used measure for trade openness. Data are taken from the Penn World Tables (PWT) Version 6.1 (Heston et al., 2002). For balancing out the skewed distribution, we use the natural logarithm for this variable. A one-year lag of the variable is appropriate in order to avoid the endogeneity problem of this relationship.

\section{Economic Liberalization}

For the process of economic opening we use the CACAO dataset which has been collected at the University of Konstanz (Martin, 2005). This index 
measures exchange arrangements and restrictions on an ordinal, 7-point scale. It is based on a combination of trade policies and institutional arrangements taken from the annual publication of the IMF 'Report on Exchange Arrangement and Exchange Restrictions'. It encompasses 90 developing countries during the period from 1978 to 2000. The advantage of this dataset is that, by taking into account the institutional settings necessary for the process of liberalizing the domestic economy, it is more fine-tuned than other instruments which often neglect the regulatory measures that a government has introduced but only rely on information about foreign exchanges (Martin, 2005). Regulatory measures are often the result of bargaining processes and therefore represent negotiated outcomes. This, however, is exactly the point in time when we expect most conflict. Consequently, the CACAO index is suitable to capture the short-term effects of economic liberalization. We measure the liberalization process as a change in the CACAO indicator. Due to the ordinal character of the measure, we use a value of 1 if liberalization took place, -1 if a country became more restrictive, and 0 if no change took place. We use a one-year lag of this variable.

\section{Regime Type}

Using the Polity IV data (Marshall and Jaggers, 2000), we add a variable for regime type together with its squared term, lagged by one year, to account for the assumed inverted U-curve of the democracy-civil war nexus (Hegre et al., 2001). Polity combines various institutional characteristics of a political system - openness and competitiveness of executive recruitment, constraints on the chief executive, regulation and competitiveness of political participation - to an index ranging from -10 for autocracies to +10 for democracies. We added 11 points to each value to have the regime variable on a scale from 1 to 21 .

\section{Development}

A higher stage of development is expected to be related to higher political stability as wealthier countries have more resources at their disposition that could be invested in social insurance services and other distributive measures. This follows from the fact that with higher per capita income, the state is provided with a broader tax base (de Soysa, 2002). Low levels of development reduce, conversely, the opportunity costs for rebellion (Collier 2001; Collier and Hoeffler, 1998, 2004). Economic development will be measured by GDP per capita with data from the PWT Version 6.1. Here again, the skewed nature of the variable has to be accounted for by using the natural logarithm, in addition to a one year lag to avoid endogeneity. 


\section{Population Size}

Population is an important control variable in connection with economic liberalization and conflict for two reasons. First, bigger countries are considered to be less open to the world market as they are able to satisfy the majority of demands within their home market (Alesina and Wacziarg, 1998). Second, Collier and Hoeffler $(1998,2004)$ find a positive relationship between the size of the population and the onset of conflict. For the population size we use data from the PWT Version 6.1. As the variable has a skewed distribution, the natural logarithm is used.

\section{Mountainous Terrain}

A rough terrain is favourable to civil wars as it provides a hideout for insurgents, difficult to be traced by government forces (Fearon and Laitin, 2003). Mountainous terrain might also be related to lower levels of trade as it inhibits transportation. We use information on rough terrain from Fearon and Laitin's (2003) data which measures the proportion of the country that is mountainous.

\section{IMF Flows}

We use concessional and non-concessional net financial flows from the IMF in relation to a country's GDP to control for the impact of these requirements. Net financial flows are disbursement of loans and credits less repayments of principal. Concessional assistance is provided through the concessional lending facilities and non-concessional flows are the credit provided by the IMF with the principal purpose to meet balance of payments needs. Data are available from the World Development Indicators (1999).

\section{Notes}

Previous versions of this article were presented at the 2003 general conference of the European Consortium for Political Research in Marburg, the Centre for the Study of Civil Wars in Oslo, and the Norwegian University for Science and Technology in Trondheim. We would like to thank the participants, Håvard Hegre, Indra de Soysa, Erich Weede and two referees for their helpful comments. Research support by the German Peace Research Foundation is gratefully acknowledged. The replication data set and the log-file of the analyses are available at http://www.uni-konstanz.de/ FuF/Verwiss/GSchneider/. 
1. Collier and Hoeffler (2002) also employ Africa as a case to illustrate their argument that poverty is a root cause of conflict.

2. The CACAO index reflects actual foreign economic policy-making rather than the output of economic interactions, as the conventionally used trade-throughGDP ratio does. See Martin (2005) as well as the appendix of this article for a fuller description of the data set.

3 . The first derivative $2 b l x+b 2$ of the square function equals 0 at the inflexion point $\mathrm{xi}$ : $\mathrm{xi}=-\mathrm{b} 2 /\left(2^{*} \mathrm{bl}\right)$. Based on the results reported in the first column of Table 1 we calculated the inflection point as $-0.3470 /\left(2^{*}-0.0104\right)$ which equals 16.68. From this number we subtracted 11 points to return to the original Polity IV scale and thus have a value of 5.68.

4. We also estimated a model with a linear term of the democracy variable only. The coefficient was positive and highly significant. This is consistent with the finding of a curvilinear character of this relationship reported above as for most cases further democratization leads to more instability.

5. We examined additional control variables to avoid omitted variable bias. Cultural diversity is frequently mentioned as a source of domestic instability. Ethnolinguistic fractionalization and its squared term (Fearon and Laitin, 2003) as well as various variables related to the number and size of ethnic, religious and linguistic groups (Ellingsen, 2000) were tested and some were significant but had no effect on our variables of main interest. As discussed by Collier and Hoeffler (2004), the length of the period of peace is an important control variable as it accounts for the gradual depreciation of military arms and skills but also can reflect declining grievances resulting from the last conflict. Besides its theoretical importance, this variable is a control for temporal dependence (Beck et al., 1998). Internal war in the past is calculated as the number of years since the last conflict with the program BTSCS Data Analysis Utility Version 4.0.4. (Tucker, 1999) and is included together with three splines in our model. The peace-years-correction and its splines were jointly significant at $p<.13$ and had no effect on the openness and liberalization variables. Our results also hold when controlling for diffusion effects, measured as a dummy variable for civil wars in the country's neighbouring states. We also controlled for additional variables used by Fearon and Laitin (2003), such as the existence of new states, measured as indicator for countries' independence in their first or second year, and political instability, measured as a change of three or more points on the Polity scale (data taken from Fearon and Laitin, 2003); the variables were insignificant. Furthermore, we altered our sample by including the North African countries, again without changed results.

6. We conducted tests with different estimation models. The rho in the panel estimation was very small and statistically not significant indicating that estimation with a simple pooled model is sufficient. In any case, our results hold in random-effects, fixed-effects, population-averaged and rare events logit models.

7. Note that we additionally tested in our statistical analyses various variables that are related to the argument that measures related to economic liberalization 
under the structural adjustment programmes, such as reducing government consumption and military expenditure, increase political unrest.

8. We chose Guinea-Bissau because at first sight the other cases evolve around minorities. The conflicts in Rwanda and Burundi are related to the tensions between the Hutu and the Tutsi. The conflicts in Mali and Niger involve the minority of the Tuareg. Thus, the case of Guinea-Bissau was the most appropriate option.

9. In December 1998, Conté again won the most recent presidential election with an absolute majority.

10. International election observers withdrew from the first presidential elections because there was no guarantee of free and fair elections.

11. Conté declared on at least one occasion that he would only agree to increased basic food prices following the SAP when a wage increase of public employees came first.

\section{References}

Acemoglu, Daron, Simon Johnson and James A. Robinson (2003) 'An African Success Story', in Dani Rodrik (ed.) In Search of Prosperiy: Analytical Narratives on Economic Growth, pp. 80-122. Princeton, NJ: Princeton University Press.

Aguilar, Renato and Åsa Stenman (1997) 'Guinea-Bissau: From Structural Adjustment to Economic Integration', Afrika Spektrum 32(1): 71-96.

Alesina, Alberto and Romain Wacziarg (1998) 'Openness, Country Size and Government', Journal of Public Economics 69: 305-21.

Archiv der Gegenwart (Keesing's Archiv der Gegenwart) 1985-2000, Sankt Augustin: Siegler \& Co.

Azam, Jean-Paul (2001) 'The Redistributive State and Conflict in Africa', Journal of Peace Research 38(4): 429-44.

Bates, Robert (1981) States and Markets in Tropical Africa: The Political Basis of Agricultural Policy. Berkeley, CA: University of California Press.

Beck, Nathaniel, Jonathan N. Katz and Richard Tucker (1998) 'Taking Time Seriously in Binary Time-Series-Cross-Section Analysis', American Journal of Political Science 42(4): 1260-88.

Bigsten, Arne and Dick Durevall (2002) 'Is Globalisation Good for Africa?', Working Papers in Economics No. 67. Göteborg University: Departments of Economics.

Brennan, Teresa (2003) Globalization and its Terrors. London: Routledge.

Bussmann, Margit, Harald Scheuthle and Gerald Schneider (2003) 'Die "Friedensdividende" der Globalisierung: Außenwirtschaftliche Öffnung und innenpolitische Instabilität', Politische Vierteljahresschrift 44(3): 302-24.

Bussmann, Margit and Gerald Schneider (2004) 'Foreign Economic Liberalization and Civil War', unpublished manuscript, University of Konstanz.

Campell, Bonnie and Jennifer A. Clapp (1995) 'Guinea's Economic Performance under Structural Adjustment: Importance of Mining and Agriculture', Journal of Modern African Studies 33(3): 425-49. 
Chazan, Naomi, Robert Mortimer, John Ravenhill and Donald Rothchild (1988) Politics and Society in Contemporary Africa. London: Macmillan.

Chua, Amy (2002) World on Fire: How Exporting Free Market Democracy Breeds Ethnical Hatred and Global Instability. New York: Doubleday.

Clapp, Jennifer A. (1994) 'Explaining Policy Reform Implementation in Guinea: The Role of Both Internal and External Factors', Journal of International Development 6(3): 307-26.

Collier, Paul (2000) 'Rebellion as a Quasi-Criminal Activity', Journal of Conflict Resolution 44(6): 839-53.

Collier, Paul (2001) 'Implications of Ethnic Diversity', Economic Policy: 129-66.

Collier, Paul and Jan Willem Gunning (1999) 'Explaining African Economic Performance', Journal of Economic Literature 37: 64-111.

Collier, Paul, and Anke Hoeffler (1998) 'On Economic Causes of Civil War', Oxford Economic Papers 50: 563-73.

Collier, Paul and Anke Hoeffler (2002) 'On the Incidence of Civil War in Africa', Journal of Conflict Resolution 46: 13-28.

Collier, Paul and Anke Hoeffler (2004) 'Greed and Grievance in Civil War', Oxford Economic Papers 56: 563-95.

Collier, Paul, Lani Elliott, Håvard Hegre, Anke Hoeffler, Martha Reynal-Querol and Nicholas Sambanis (2003) Breaking the Conflict Trap: Civil War and Development Policy. Washington, DC: World Bank/Oxford University Press.

de Soysa, Indra (2002) 'Paradise is a Bazaar? Greed, Creed, and Governance in Civil War, 1989-99', Journal of Peace Research 39(4): 395-416.

de Soysa, Indra and Angelika Wagner (2003) 'Global Market, Local Mayhem? Foreign Investment, Trade Openness, State Capacity, and Civil War, 1989-2000', paper presented at the Joint Sessions of Workshops of the ECPR, Edinburgh.

Easterly, William and Ross Levine (1997) 'Africa's Growth Tragedy: Policies and Ethnic Divisions', Quarterly Journal of Economics 112(November): 1203-50.

Elbadawi, Ibrahim and Nicholas Sambanis (2000) 'Why are there so Many Civil Wars in Africa? Understanding and Preventing Violent Conflict', Journal of African Economies 9: 244-69.

Ellingsen, Tanja (2000) 'Colorful Community or Ethnic Witches' Brew? Multiethnicity and Domestic Conflict During and After the Cold War', Journal of Conflict Resolution 44(2): 228-49.

Fearon, James. D. and David D. Laitin (2003) 'Ethnicity, Insurgency, and Civil War', American Political Science Review 97(1): 75-90.

Fischer, Stanley (2003) 'Globalization and its Challenges', American Economic Review 93(2): 1-30.

Forrest, Joshua B. (1987) 'Guinea-Bissau Since Independence: A Decade of Domestic Power Struggles', The Journal of Modern African Studies 25(1): 95-116.

Gaillard, Gérald (1999) 'Guinée-Bissau: un pas douloureux vers la démocratie', Afrique contemporaine 191(3): 43-57.

Geddes, Barbara (1994) 'How Politicans Decide Who Bears the Costs of Liberal- 
ization: Latin American, South European, and African Experiences', in Ivan Berend (ed.) Transition to a Market Economy at the End of the 20th Century, pp. 203-28. München: Südosteuropa-Gesellschaft.

Gleditsch, Nils Petter, Peter Wallensteen, Mikael Eriksson, Margareta Sollenberg and Håvard Strand. (2002) 'Armed Conflict 1946-2001: A New Dataset', Journal of Peace Research 39(5): 615-37.

Grosh, Barbara (1994) 'Through the Structural Adjustment Minefield: Politics in an Era of Economic Liberalization', in Jennifer A. Widner (ed.) Economic Change and Political Liberalization in sub-Saharan Africa, pp. 29-46. Baltimore, MD: Johns Hopkins University Press.

Harff, Barbara (2003) 'No Lessons Learned from the Holocaust? Assessing Risks of Genocide and Political Mass Murder since 1955', American Political Science Review 97(1): 57-73.

Hegre, Håvard, Tanja Ellingsen, Scott Gates and Nils Petter Gleditsch (2001) 'Towards a Democratic Civil Peace? Democracy, Political Change, and Civil War 1816-1992', American Political Science Review 95(1): 17-33.

Hegre, Håvard, Ranveig Gissinger and Nils Petter Gleditsch (2003) 'Globalization and Internal Conflict', in Gerald Schneider, Katherine Barbieri and Nils Petter Gleditsch (eds) Globalization and Armed Conflict, pp. 251-75. Lanham, MD: Rowman \& Littlefield.

Heston, Alan, Robert Summers and Bettina Aten (2002) Penn World Table Version 6.1, Center for International Comparisons at the University of Pennsylvania (CICUP).

Institut für Afrika-Kunde (ed.) (1999-2000) Afrika Jabrbuch: Politik, Wirtschaft und Gesellschaft in Afrika südlich der Sahara. Opladen: Leske \& Budrich.

Jensen, Nathan (2004) 'Crisis, Conditions, and Capital: The Effect of International Monetary Fund Agreements on Foreign Direct Investment Inflows', Journal of Conflict Resolution 48(2): 194-210.

Kovsted, Jens and Finn Tarp (1999) 'Guinea-Bissau: War, Reconstruction and Reform', WIDER Working Paper No. 168.

Marshall, Monty G. and Keith Jaggers (2000) 'Polity IV Project: Dataset Users Manual', http://www.bsos.umd.edu/cidcm/inscr/polity/index.htm

Martin, Christian W. (2005) Die doppelte Transformation. Wiesbaden: Verlag der Sozialwissenschaften.

Matovu, John. M. and Francis Stewart (2001) 'Uganda', in Francis Stewart, Valpy Fitzgerald and Associates (eds) War and Underdevelopment, Volume II: Country Experiences, pp. 240-88. Oxford: Oxford University Press.

Monteiro, Antonio. I. (1996) 'O programa de ajustamento estrutural na GuinéBissau análise dos efeitos sócio-económicos’, Bissau Instituto Nacional de Estudos e Pesquisa.

Murdoch, James C. and Todd Sandler (2002) 'Economic Growth, Civil Wars, and Spatial Spillovers', Journal of Conflict Resolution 46(1): 91-110.

Oatley, Thomas (2004) 'Why are Stabilizations Sometimes Delayed? Reevaluating the Regime-Type Hypothesis', Comparative Political Studies 37(3): 286-312. 
Olsson, Ola and Heather Congdon Fors (2004) 'Congo: The Prize of Predation', Journal of Peace Research 41: 321-36.

Rodrik, Dani (1994) 'The Rush to Free Trade in the Developing World: Why So Late? Why Now? Will It Last?', in Stephan Haggard and Steven B. Webb (eds) Voting for Reform: Democracy, Political Liberalization, and Economic Adjustment, pp. 61-88. New York: Oxford University Press.

Rogowski, Ronald (1989) Commerce and Coalitions. How Trade Affects Domestic Political Alignments. Princeton, NJ: Princeton University Press.

Rudebeck, Lars (2001) Colapso e Reconstrução Política na Guiné-Bissau 1998-2000. Um Estudo de Democratização Difícil. Uppsala: Nordista Afrikainstitutet.

Sachs, Jeffrey D. and Andrew Warner (1995) 'Economic Reform and the Process of Global Integration', Brookings Papers on Economic Activity 1: 1-118.

Sahn, David E., Paul A. Dorosh and Stephen D. Younger (1997) Structural Adjustment Reconsidered. Cambridge: Cambridge University Press.

Schiefer, Ulrich (2002) 'Von allen guten Geistern verlassen? Guinea-Bissau: Entwicklungspolitik und der Zusammenbruch afrikanischer Gesellschaften', Hamburger Beiträge zur Afrika-Kunde 70. Hamburg: Institut für Afrika Kunde.

Stewart, Francis and Valpy Fitzgerald (2001) 'The Cost of War in Poor Countries: Conclusions and Policy Recommendations', in Francis Stewart, Valpy Fitzgerald and Associates (eds) War and Underdevelopment. Volume 1: The Economic and Social Consequences of Conflict, pp. 225-45. Oxford: Oxford University Press.

Stiglitz, Joseph E. (2002) Globalization and its Discontents. London: Allen Lane.

Stryker, J. Dirck (1990) 'Adjustment in West Africa: The Guinea Experience', in F. Desmond McCarthy (ed.) Problems of Developing Countries in the 1990s. Vol. II Country Studies, pp. 183-202. Washington, DC: World Bank.

Teriba, Owodunni (1991) 'Country Case Studies', in Adebayo Adedeji, Owodunni Teriba and Patrick Bugembe (eds) The Challenge of African economic recovery and development, pp. 69-106. London: Frank Cass.

Thirlwall, A.P. (2003) Growth and Development: With Special References to Developing Economies. London: Palgrave Macmillan.

Tucker, Richard (1999) 'BTSCS: A Binary Time-Series-Cross-Section Data Analysis Utility', Version 4.0.4. Cambridge, MA: Harvard University. http://www.fas. harvard.edu/ rtucker/programs/btscs/btscs.html

Van de Walle, Nicolas (2001) African Economies and the Politics of Permanent Crises, 1979-1999. Cambridge: Cambridge University Press.

Walter, Stefanie (2003) 'Trade Liberalization and Domestic Political Instability: The Case of Argentina', paper presented at the Marburg General Conference of the ECPR, September, Marburg, Germany.

Weede, Erich and Eduard N. Muller (1998) 'Rebellion, Violence and Revolution: A Rational Choice Perspective', Journal of Peace Research 35(1): 43-59.

Wegemund, Regina (1999) 'Die CPLP und der Bürgerkrieg in Guinea-Bissau', Internationales Afrikaforum 35(2): 165-76.

World Bank (1999) World Development Indicators 1999 CD-ROM. Washington, DC: World Bank. 
Yusuf, Shahid and Joseph Stiglitz (2001) 'Development Issues: Settled and Open', in Gerald M. Meier and Joseph Stiglitz (eds) Frontiers of Development Economics: The Future in Perspectives, pp. 227-68. Oxford: Oxford University Press,

Zejan, Mario and Ari Kokko (1998) 'Guinea-Bissau', in Howard White (ed.) Aid and Macroeconomic Performance. Theory, Empirical Evidence and Four Country Cases, pp. 109-38. London: Macmillan. 